\title{
Анализа говорних чинова женских и мушких ликова у уџбеницима италијанског језика као страног из перспективе рода
}

\author{
Наташа Д. Вученовић* \\ Универзитет у Бањој Луци, Филолошки факултет, Катедра италијанских студија
}

\begin{abstract}
Кључне речи:
уџбеници

страни

говорни чинови

женски говор

мушки говор

сексизам
\end{abstract}

италијански језик као

родне идеологије

\section{Апстракт}

Рад се надовезује на корпус истраживања о родним стереотипима и сексизму у уџбеницима страних језика, адресирајући ово питање кроз анализу комуникативних образаца женских и мушких ликова. Родни стереотипи и сексизам тумаче се као рефлекс родних идеологија кроз које се неједнаки односи моћи предочавају као унапред задато природно стање. Истраживачке методе које се користе су теорија говорних чинова у функцији квалитативне анализе, као и критичка анализа дискурса, која је полазна тачка за анализу идеолошких механизама унутар дискурса. Циљ истраживања је да се испита да ли су у дијалошким секвенцама присутни обрасци и стратегије карактеристичне за тзв. женски говор; да ли укључивање прагматичког аспекта може да открије родно условљене разлике у говорним чиновима; да ли искази женских и мушких ликова садрже родне стереотипе и сексистичке конотације који одражавају традиционалну родну хијерархију. Резултати указују на то да женски ликови користе жалбе и опомене више него мушки, међутим, жалбе женских ликова изречене су на директан начин, док су код мушких ликова уочљиве стратегије учтивости, чиме се доводи у питање концепт женског говора и отвара простор за потврду теорија о роду као перформативном чину. Надаље, произилази да разлике у говору женских и мушких ликова суштински не проистичу из врсте говорног чина, већ су контекстуално условљене. (примљено: 4. августа 2021; прихваћено: 16. септембра 2021) www.anali.fil.bg.ac.rs AHAЛИ

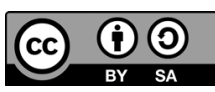

Филолошки факултет

Катедра италијанских студија

Булевар војводе Петра Бојовића 1

78000 Бања Лука, Босна и Херцеговина natasa.vucenovic@flf.unibl.org 


\section{1. Увод}

Зачеци истраживања о родним стереотипима и различитим видовима сексизма у уџбеницима страних језика датирају још из шездесетих година прошлог века (Graci, 1989: 478), а данас постоји веома опсежан корпус литературе која је настала у оквирима ове теме. Због глобалне распрострањености енглеског језика и lingua franca статуса који има, највећи део истраживања бави се уџбеницима енглеског језика као страног, док проблем укорењености родних стереотипа и родних идеологија у уџбеницима осталих страних језика није у довољној мери истражен. Један од примера представљају уџбеници италијанског језика, којима је како у италијанској и српској тако и у целокупној академској заједници посвећено свега неколико студија ${ }^{1}$.

У најопштијим цртама, квалитативна истраживања сексизма и родних стереотипа у уџбеницима страних језика најчешће су фокусирана на приказ женских и мушких ликова у приватној и професионалној сфери, опис њихових карактерних црта и спољашњег изгледа, навика, интересовања, као и на издвајање облика језичког сексизма, најчешће исказаног кроз употребу мушког рода као свеобухватног и генеричког (в. Hartman/Judd, 1978; Hellinger, 1980; Porreca, 1984; Rifkin, 1998; Ansary, Babaii, 2003; Gupta/Yin, 2009; Johansson/ Malmsjö, 2009; Lee/Collins, 2010; Barton/Sakwa, 2012; Kološ, 2018; Angelini/ Tarantola, 2020). Оно што је великим делом запостављено јесте квалитативна анализа говора, односно, дијалошких секвенци женских и мушких ликова из родне перспективе. Анализе дијалошких модела претежно су квантитативног типа и у њима се даје статистички приказ заступљености женских и мушких ликова, полазећи од параметара као што су укупан број случајева када женски и мушки ликови иницирају разговор, укупан број њиховог смењивања у току једног дијалога, укупан број изговорених речи (в. Poulou, 1997; Johansson/ Malmsjö, 2009). Квантитативна анализа има потенцијал да поткрепљивањем конкретних статистичких података укаже на евентуалну презаступљеност једног рода у односу на други (Johansson/Malmsjö, 2009: 20), што свакако може да буде један од показатеља родне неравноправности. С друге стране, Поулоу (Poulou, 1997) кроз анализу дискурзивних улога женских и мушких ликова открива да су у неким дијалозима женски ликови квантитативно заступљенији у односу на мушке, међутим, тек укључивањем квалитативне анализе открива да су у комуникативним обрасцима ликова уткани родни стереотипи - код женских ликова је доминантна експресивна функција, попут исказивања осећања, док мушки ликови имају доминантну улогу у објашњавању и усмеравању (нпр. женски ликови траже док мушки ликови пружају просторно-временске инфор-

1 Према актуелним сазнањима тема родних стереотипа у уџбеницима италијанског језика као страног до сада је адресирана само у следећим радовима: рад ауторке Аријане Карте (Arianna Carta) Differenze di genere nella didatica per persone alloglotte објављен 2003. год. у часопису Linguistica; дипломски рад Софије Колош Gli stereotipi di genere nei manuali d'italiano који је одбрањен 2018. године на Филозофском факултету Универзитета у Загребу; рад Елене Анђелини (Elena Angelini) и Силвије Тарантоле (Silvia Tarantola) La rappresentazione dell'immagine di genere (maschile e femminile) nei manuali di italiano L2 објављен 2020. године у часопису Bollettino Itals. 
мације) (Poulou, 1997: 71). Ови подаци јасно указују на то да родне асиметрије у говору женских и мушких ликова, и када нису присутне на квантитативном нивоу, могу да буду уцртане у комуникативне обрасце, које је могуће сагледати само кроз примену квалитативне анализе.

У раду се полази од претпоставке да су у комуникативним обрасцима женских и мушких ликова уцртани родни стереотипи, које тумачимо као рефлекс родних идеологија чијим се репродуковањем доприноси одржавању родног statusa quo. Користећи се теоријом говорних чинова класификоваћемо иницијалне исказе женских и мушких ликова, а потом их интерпретирати из угла критичке анализе дискурса. Претпоставка је да ће анализа говорних чинова женских и мушких ликова омогућити издвајање комуникативних образаца у којима су садржани родни стереотипи о друштвеним улогама жена и мушкараца, као и да ће осликати родне стереотипе који се односе на свакодневне активности жена и мушкараца пројектоване кроз говор, што ће се свеукупно, из угла критичке анализе дискурса, интерпретирати као употреба језика у сврху одржавања доминантних родних идеологија.

\section{2. Развој истраживања о односу језика и рода}

Истраживања о интеракцији језика и рода у друштву могу се поделити у три периода (Filipović, 2018: 190). Први период подудара се са другим таласом феминизма (Bucholtz, 2014: 25) и карактерише га спознаја о томе да се кроз језик рефлектују родне неједнакости и дискриминација жена (Pauwels, 2003: 551). Овај период обележила је књига Робин Лејкоф (Lakoff, 1973) Језик и место жене, која почива на претпоставци да су женски и мушки говор два различита варијетета - први одликују комуникативне стратегије попут индиректности и учтивости, које одражавају несигурност и подређеност жена у друштву, док је други одраз доминације мушкараца. У складу са овим претпоставкама настаје теорија доминације. Неки од примера језичке надмоћи подразумевају тенденцију мушкараца да прекидају жене или да у формалним разговорима говоре више од њих (Filipović, 2018: 190-191).

Теорија доминације осамдесетих година прошлог века замењена је теоријом различитости (други назив је модел две културе; енг. two-cultures model), која полази од претпоставке да жене и мушкарци говоре различитим дијалектима, што се објашњава различитостима у процесу социјализације девојчица и дечака (Filipović, 2018: 190). За разлику од теорије доминације, ова теорија различитост женског говора у односу на мушки не посматра кроз призму инфериорног положаја жене у друштву, већ тежи ка томе да жене постави у равноправнији положај, истичући позитивне аспекте различитости, као аутентичне $и$ дистинктивне црте културне традиције жена (Cameron, 1995: 39). Коутс (Coates, 2013: 6) тако сматра да је један од циљева женске интеракције показивање солидарности и одржавање добрих социјалних односа. Међу најзначајнијим ауторкама овог периода издваја се Дебора Тенен (Tannen, 1991), која је у својој популарној књизи Ти једноставно не разумеш (You just don't understand) изнела 
ставове да дечаци и девојчице језик користе у супротне сврхе: за прве је он средство надметања и доказивања моћи, док је за друге средство успостављања интимности и поверења.

Деведесетих година прошлог века Тенен (Tannen, 1991) почиње да спроводи анализе конверзације које указују на то да конверзацијске стратегије не морају бити у директној корелацији са родом, те да говорнице и говорници могу да користе и комбинују различите индивидуалне стилове како би остварили своје циљеве у комуникацији (нпр. учтив приступ који није сигнал субмисивности, већ средство преко којег се долази до жељеног циља). Она уочава како полна или родна дихотомија не може да обухвати сву различитост језичких понашања која су у корелацији са родом (Filipović, 2018: 194), што доводи до формирања треће парадигме у области студија језика и рода, која се одређује као теорија перформативности. Ову теорију развија америчка постструктуралистичка филозофкиња и теоретичарка рода Џудит Батлер (Judith Butler), која род посматра као динамичку категорију која се развија током целог живота људске јединке (Filipović, 2018: 194). У кључу ове теорије корелације између језика и рода не треба посматрати кроз дихотомију полне биолошке детерминанте, већ кроз призму сложених друштвених фактора (економске и друштвене класе, етницитета, политичких и верских убеђења), односно идеологија и културних модела које обликују наш идентитет (Filipović, 2018: 194).

Одлике које су одређене као специфичности женске вербалне комуникације повезују се са несигурношћу, неасертивношћу, покорношћу, учтивости, префињености, кооперативности, међутим, ови наводи су у више наврата критиковани због непримерених генерализација до којих долази зато што се из вида испушта чињеница да разлике у говору не долазе искључиво као резултат полних одлика, већ језичких и родних идеологија које нису фиксне одлике друштва већ категорије које варирају у односу на друштвено-културни контекст (Грубор, 2016: 87). Због сложености односа језика и рода неки аутори и ауторке сматрају да је род неопходно посматрати са прагматичког аспекта и у обзир узети дискурзивне обрасце који осликавају конкретне стратегије којима жене и мушкарци прибегавају за постизање циљева: наредбе, ублажене форме, оповргавања, прекидања, понављања, извињења, увреде (Грубор, 2016: 8). Ове стратегије могу да буду родно условљене, а могу и да рефлектују паралингвистичке одлике које се типично асоцирају уз женски или мушки говор: солидарност, компетитивност, емоционалност, оклевање, сервилност, несигурност или доминацију (Грубор, 2016: 88). Узимајући у обзир наведена разматрања, у овом раду ћемо стереотипне одлике женског говора посматрати са прагматичког аспекта.

\section{3. Родни стереотипи и родне идеологије}

Родне стереотипе можемо дефинисати као генерализована и унапред формирана мишљења о атрибутима и карактеристикама жена и мушкараца, као и о улогама за које се сматра да су друштвено прикладне (United Nations Human Rights). Кузмановић-Јовановић (2013: 35) истиче како су ове улоге засноване и 
ограничене полом, што родне стереотипе чини вишеструко штетнима, будући да могу ограничити развој природних талената и способности дечака и девојчица, то јест мушкараца и жена, као и њихове могућности у животу. Стереотипи нису само дескриптивни, већ и прескриптивни, будући да у великој мери условљавају понашања, изборе и одлуке жена и мушкараца (Brescoll/Uhlmann, 2005: 436).

Сматра се да се у сржи родних стереотипа налазе две димензије - предузимљивост (енг. agency) и блискост (енг. communion), које рефлектују есенцијалистичке погледе о природи жена и мушкараца (Sczesny et al., 2019: 105). Блискост инкорпорира особине као што су емотивност, топлина, брига за добробит других и типично се веже за жене, док предузмљивост обухвата способност, ауторитет, независност, $и$ асоцира се уз мушкарце (Haines et al., 2016: 2). Из ове категорије произилази читав низ особина и улога које се приписују женама и мушкарцима (нпр. у женској је природи да одгаја децу и буде зависна од мушкарца, док мушкарац има дужност да економски обезбеди породицу, те да као глава куће покаже ауторитет и одржи традиционалну хијерархију). Родни стереотипи дакле могу да буду позитивни и негативни и њима су изложени и жене и мушкарци, али су њихове друштвене последице много озбиљније за жене, зато што веома често заправо претпостављају и легитимизују њихову потчињеност и инфериорност.

Moћ је, како запажа Мери Талбот (Talbot, 2003: 471), кључан појам за разумевање родних стереотипа, јер су они обично усмерени ка подређеним групама (нпр. етничке мањине или жене) и стога имају важну улогу у борби за остваривање друштвене хегемоније. Родни стереотипи имају дакле јасну хијерархијску компоненту кроз коју се очитава неједнака расподела односа моћи у друштву. Функција стереотипа је стога и оправдавајућа, будући да они легитимишу неравноправност полова и дискриминацију жена (Weary et al., 2001). Родни стереотипи садрже снажну идеолошку компоненту, јер је њихова функција одржавање и оправдање патријархата (Glick/Rudman, 2010: 330). Талбот (Talbot, 2003: 472) наводи да постоји снажна корелација између родних стереотипа и родних идеологија, истичући да су стереотипи уствари идеолошки условљени обрасци очекиваних понашања:

Родни стереотипи су уско везани са родним идеологијама и подржавају их. Ако их посматрамо као идеолошке прескриптивне моделе понашања, онда то значи да појединци морају да преузму стереотипне улоге које се од њих очекују [...] [Стереотипи] имају функцију одржавања хегемонијске доминације мушкараца и потчињености жена.

\section{4. Уџбенички корпус и критеријуми одабира}

Корпус је сачињен од пет уџбеника италијанског језика као страног који се користе (или су у протеклој деценији кориштени) у настави италијанског језика на Филолошком факултету Универзитета у Бањој Луци. Одабрани уџбеници 
су Qui Italia (2002; издавач Le Monnier), Nuovo progetto italiano (2006; издавач Bonacci Editore), Chiaro (2010; издавач Alma Edizioni), Facilissimo (2014; издавач Alma Edizioni) и Via del Corso (2018; издавач Edizioni Edilingua). Сви уџбеници су намењени почетницима; одговарају A1-A2 3ЕО нивоу; засновани су на комуникативном приступу; објавиле су их познате италијанске издавачке куће: Alma Edizioni, Bonacci Editore, Edizioni Edilingua, Le Monnier, од којих су прве три специјализоване за креирање и припрему наставних материјала, уџбеника и приручника из области италијанског као страног језика.

Важно је навести да су сви уџбеници изашли из штампе након 1998. године, која је издвојена јер је тада у Италији покренут Polite - пројекат о постизању родне равноправности у образовању, у оквиру чијих је стратешких циљева истакнуто и искључивање сексизма и родних стереотипа из уџбеника. У другој фази пројекта формулисан је Кодекс понашања издавачких кућа Италије, којим је предвиђено да уџбеници треба да укључују критеријуме родне равноправности (Mapelli, 2008: 23), а примену датих смерница испитаћемо на примеру дијалошких секвенци ликова. Уџбеници су објављени у шеснаестогодишњем периоду, размак између сваког обухвата четири године, а ова хронолошка линија омогућава преглед евентуалних промена у родним идеологијама.

\section{5. Методолошки поступак}

5.1. Теорија говорних чинова у функцији квалитативне методе

У истраживање ћемо укључити прагматички аспекат, или прецизније теорију говорних чинова, за коју смо се определили зато што је подесна за анализу дијалога у уџбеницима, с обзиром на то да је сам говорни чин заправо „основни облик реализације дијалога“ (Ivanetić, 1995: 13). Надаље, за испитивање корелација између језика и рода прагматички аспекат је важан зато што се кроз говорне чинове производе друштвена значења, чијом анализом можемо разоткрити односе моћи у друштву. Ван Дијк (van Dijk, 1989: 29) наводи да се друштвене неједнакости између различитих група, нпр. жена и мушкараца, испољавају кроз асиметрије присутне у свакодневном разговору, које су, између осталог, посебно евидентне и у кориштењу говорних чинова и одабиру теме разговора.

Један од приступа који су обележили савремена проучавања у оквиру прагматике јесте већ поменута теорија говорних чинова (енг. speech act theory), која исказ тумачи као средство деловања и вид друштвене акције са директним последицама на ванјезичку стварност. Теорија говорних чинова развила се из филозофије језика средином XX века, а сам појам „говорни чин“ увео је филозоф Џон Остин (John Austin) у књизи Како деловати речима (How to Do Things with Words) објављеној 1962. године. Остин и његов ученик Џон Серл (John Searle) понудили су и прве класификације говорних чинова, које су неки аутори накнадно допунили или делимично модификовали, најчешће терминолошки, али углавном задржавајући првобитно значење појмова (Bach, 2006: 149-150). Остин разликује три нивоа говорног чина (Bach, 2006: 150):

1) локуциони чин (locutionary act): сам исказ, изговорене речи; 
2) илокуциони чин (illocutionary act): сврха исказа;

3) перлокуциони чин (perlocutionary act): ефекат исказа на слушаоца.

Илокуциона функција говорног чина заузима централно место у прагмалингвистичким истраживањима. Илокуциони чин посматра се као радња извршена посредством говора, која може да има конкретне друштвене последице (Milosavljević, 2007: 29). Када је реч о самој класификацији илокуционих чинова, определили смо се за Бахову варијанту (Bach, 2006: 151-156), јер је подела коју предлаже најпогоднија за анализу жељених аспеката овог дела истраживања. Таксономија коју нуди обухвата четири велике групе илокуционих говорних чинова:

1) констативи: тврдити, наводити, најавити, одговорити, приписати, класификовати, исказати сагласност, потврдити, претпостављати, негирати, исказати несагласност, открити, оспорити, идентификовати, информисати, инсистирати, предвидети, рангирати, саопштити, изнети, уговорити

2) директиви: саветовати, опоменути, питати, преклињати, распустити, забранити, дати инструкције, наредити, дозволити, захтевати, изискивати, сугерисати, убедити, упозорити

3) комисиви: слагати се, кладити се, гарантовати, позвати, понудити, обећати, закунути се, исказати добровољност

4) признана: извинити се, поистоветити се, честитати, поздравити, захвалити, прихватити.

У крос-културном истраживању говорних чинова установљена је корелација са родом - емпиријски подаци показали су да жене више употребљавају комисиве, а мушкарци директиве (Clyne, 1995: 70-77). У току анализе посматраћемо да ли су ови комуникацијски обрасци уочљиви и у иницијалним исказима женских и мушких ликова, осврћући се пре свега на наредбе и критике и начин на који су оне условљене родом. Истаћи ћемо важност социјалног контекста, који је неопходно узети у обзир као један од одређујућих фактора приликом анализе рода у комуникацији (Mills, 2003: 2). Контекст ћемо посматрати кроз приватну и јавну сферу, као и кроз критеријум друштвених улога и релација саговорника и саговорница (van Dijk, 2008: 22) (нпр. директор и секретарица, или обрнуто), који је нарочито важан јер омогућава осврт на систем односа моћи. Посматрање контекста је стога кључно зато што нам омогућава увид у специфичност ситуација у којима женски или мушки ликови започињу разговор (нпр. за кога је типичније да у јавном контексту тражи просторне и временске информације, или код кога је израженија склоност да успостави први корак и искаже емотивну заинтересованост за супротни пол), што нам даље може открити присуство патријархалних родних идеологија у комуникативним обрасцима.

Говорни чинови корелирају са учтивошћу, зато што је сваки изговорени исказ у одређеној мери обележен постојањем учтивих стратегија или пак изостављањем истих. Генерално се сматра да жене у комуникацији показују већи степен учтивости него мушкарци, о чему сведоче и емпиријски подаци из различитих студија (Holmes, 1995: 4). У светлу теорије доминације, ова специфич- 
ност женског говора тумачи се као одраз њихове немоћи и подређеног положаја у друштву (в. Lakoff, 1973). Када говоримо о учтивости, неизоставно је поменути теорију учтивости (енг. politeness theory) коју су конципирали Пенелопа Браун и Стивен Левинсон (Brown/Levinson, 1987). Према овој теорији, учтивост осликава два аспекта нашег идентитета - позитиван и негативан образ (енг. positive and negative face), а у њеном корену је тежња да се у комуникацији очува властити интегритет, али и интегритет саговорника. Да би се то постигло, неопходно је поседовати емпатију и водити рачуна о стању саговорница и саговорника и ономе шта они желе (позитивна учтивост), као и избегавати претерану директност, која може да се интерпретира као наметање (негативна учтивост). Позитивна и негативна учтивост представљају две комплементарне стратегије - употребом прве наглашава се присност са саговорником, кроз неформално обраћање или кориштење жаргона којим се сигнализује припадност истој социјалној групи, док је код друге акценат на исказивању поштовања према саговорнику и његовом ауторитету (Milosavljević, 2007: 24-25). Неке од најчешћих стратегија негативне учтивости су индиректност, употреба ограда и питања, песимистични тон, апологетски тон (Brown/Levinson, 1987: 129-138). У процесу анализе говорних чинова посматраћемо да ли је учтивост наглашеније обележје говора женских или мушких ликова, или можда у овом погледу не постоје значајне разлике.

Будући да језик рефлектује стварност, кроз њега се очитавају и друштвене, односно родне неједнакости, па тако посматрањем различитих комуникативних образаца и стратегија којима у току конверзације прибегавају жене и мушкарци, можемо да откријемо и њихов статус и позицију у друштву (SmithLovin/Robinson, 1992: 122).

Анализа је ограничена на иницијалне исказе текстуалних дијалога из уџбеника у којима учествују женски и мушки ликови, будући да у њима могу бити садржани родни стереотипи и идеологије које се испољавају приликом самог избора конверзацијских тема женских и мушких ликова. Исказ може да подразумева једну реч, реченицу или секвенцу кратких реченица (Poulou, 1997: 69). Уколико се исказ састоји из више компоненти, оне се неће рашчлањивати, већ ће се посматрати као целина, у оквиру које ће се у складу са значењем и контекстом одредити примарни говорни чин (нпр. у исказу “Signora, quanta roba ha comprato! Devo aiutarLa? Posso portare io una borsa?" констатив je "Signora, quanta roba ha comprato!", док исказе “Devo aiutarLa?” и "Posso portare io una borsa?” одређујемо као комисиве. Примарна функција целог овог исказа је да се понуди помоћ, па га према томе уврштавамо у комисиве.)

\section{2. Критичка анализа дискурса}

Као што је истакнуто, родни стереотипи су нераскидиво везани за родне идеологије, будући да и сами представљају идеолошки условљене обрасце понашања, којима је циљ одржавање неједнаких односа моћи у друштву (Talbot, 2003: 472). Као најпогоднији методолошки приступ за њихову анализу намеће се критичка анализа дискурса (енг. critical discourse analysis), чијом се приме- 
ном открива „како идеологије и односи моћи обликују дискурс, а потом и какве ефекте дискурс остварује на друштвене идентитете, друштвене релације и системе знања и веровања“. (Fairclough, 1992: 12)

Идеолошке поставке су под маском здраворазумског, подразумеваног размишљања и деловања инкорпориране у језик, који представља „примарни медијум друштвене контроле и моћи“ (Fairclough, 1989: 3), па је стога критичка анализа дискурса у овом смислу „подесан метод за разоткривање скривених веза између језика, моћи и идеологије“. (Kolarić, 2008: 164) Имајући на уму везе између дискурса и идеологија, говорне чинове из корпуса ћемо интерпретирати из угла критичке анализе дискурса.

\section{6. Анализа комуникативних образаца женских и мушких ликова}

У наставку ћемо из угла теорије говорних чинова издвојити и истражити комуникативне обрасце својствене женским и мушким ликовима приликом иницирања међусобних дијалога, те ћемо посматрати у којој су мери у њима садржани родни стереотипи и родне неједнакости, и да ли су поменуте одлике условљене контекстом, или типологијим самог говорног чина. Стереотипне концепције садржане у говору женских и мушких ликова интерптерираћемо кроз призму критичке анализе дискурса, као рефлекс родних идеологија.

Међу иницијалним исказима релевантним за анализу родних односа издвајају се директиви и комисиви, који су даље класификовани у више поткатегорија.

\section{1. Директиви}

6.1.1. Питања у сврху добијања личних информација

Дијалози из ове категорије претежно се одвијају у јавном простору (нпр. факултет, менза, воз) и најчешће су неформалног, а ређе и формалног карактера. У уџбенику Qui Italia примећујемо да женски ликови започињу разговор уколико особу којој се обраћају познају од раније: Robert, a Boston studi o lavori? („Роберте, у Бостону студираш или радиш?“) (Mazzetti et al., 2002: 13); Sei inglese Robert? („Роберте, да ли си ти Енглез?“) (Mazzetti et al., 2002: 7). С друге стране, забележено је да искључиво мушки ликови иницирају разговор у ситуацијама када се саговорници међусобно не познају. У три издвојена случаја мушки ликови чине први корак при упознавању питајући за име. У првом случају разговор се одвија у возу, и формалног је карактера: Come si chiama? („Како се зовете?“) (Mazzetti et al., 2002: 20).

Други пример који издвајамо је неформалног карактера - одвија се на забави и прати упознавање Данијела и Ингрид: Come ti chiami? („Како се зовеш?“) (Mazzetti et al., 2002: 6).

Трећа ситуација такође је смештена у јавну сферу, одвија се на забави - Роберт пита Данијела за девојку коју је уочио, након чега јој Данијел прилази и пита је за име. Идентичан принцип проналазимо и у уџбенику Nuovo progetto italiano, где су присутни само примери мушких ликова који чине први корак ка 
склапању познанства са женским ликовима: Ciao, io mi chiamo Matteo. E tu come ti chiami? („Ћао, зовем се Матео. А ти, како се зовеш?“); Ciao, mi chiamo Andrea, e tu? („Ћао, зовем се Андреа, а ти?“) (Marin/Magnelli, 2006: 17).

Чињеница да није забележено да женски ликови чине први корак при упознавању супротног пола указује на традиционално утемељену социјалну конвенцију према којој је мушкарац тај који прилази жени и отпочиње интеракцију. У Nuovo progetto italiano проналазимо два дијалога у којима мушки ликови постављају питања у сврху добијања информација о њима непознатим особама женског пола. У првом примеру мушки лик пита пријатељицу (или познаницу; на основу контекста није јасна тачна природа њиховог познанства): Chi è questa ragazza? („Ко је ова девојка?“), а разлог интересовања је њен физички изглед, што нам открива и његова реакција: Che bella ragazza! („Како лепа девојка!“) (Marin/Magnelli, 2006: 12) У следећем примеру мушки лик поставља питање о девојци коју не познаје: Com’è Gloria? Bella? („Каква је Глорија? Лепа?“) (Marin/Magnelli, 2006: 143). У оба примера женски ликови су окарактерисани преко физичког изгледа, штавише, њихова лепота издваја се као главни разлог мушког интересовања. Феминистичке критичарке сматрају да су жене у западним културама још увек изразито објективизиране (Swami et al., 2010: 367), те да друштвено прописани идеали лепоте остварују репресиван утицај на жене, који се реализује кроз стереотипна уверења да је лепота есенцијална женска црта, императив за жене и најважнији женски квалитет (Scott, 1997: 12). Трагове ових стереотипних поставки проналазимо и у горенаведеним иницијалним исказима мушких ликова.

У уџбенику Chiaro имамо релативно родно уједначену расподелу исказа којима се започиње познанство, а издвојићемо један пример када мушки лик иницира упознавање и један када то чини женски лик: Ciao, io sono Paolo. E tu come ti chiami? („Ћао, ја сам Паоло. А како се ти зовеш?“) (De Savorgnani/Bergero, 2010: 11); Buongiorno. E’ libero qui? Mi chiamo Chiara Monfalco. („Добар дан. Да ли је овде слободно? Зовем се Кјара Монфалко“.) (De Savorgnani/Bergero, 2010: 11)

У уџбенику Facilissimo, у дијалогу посвећеном упознавањима, мушки лик чини први корак ка склапању познанства: Ciao, tu sei Stephanie, vero? („Ћао, ти си Стефани, је ли тако?“) (Krasa/Riboni, 2014: 18).

У уџбенику Via del Corso нисмо уочили дијалоге који садрже комуникативне формуле типичне за упознавање и успостављање првих контаката.

\subsection{2. Питања у сврху добијања просторних и временских информација}

Дијалози који се покрећу питањима овог типа симулирају интеракцију између махом непознатих особа, случајних пролазника, који у контексту јавног простора, уз формалан или неформалан тон обраћања, размењују информације које су им неопходне за реализацију неке од свакодневних активности (нпр. одлазак на станицу или у банку).

У уџбенику Qui Italia код ове врсте интеракције изражена је родна неуједначеност, јер смернице за оријентацију у простору траже само женски ликови: 
Dov'è l'ufficio informazioni? („Где су Информације?“) (Mazzetti et al., 2002: 80); Scusi, mi direbbe dov'è la biblioteca comunale? („Извините, да ли бисте ми могли рећи где се налази градска библиотека?“) (Mazzetti et al., 2002: 238).

Способност просторне оријентације код жена и мушкараца предмет је бројних научних истраживања из области когнитивне психологије. Независно од тога да ли су испитиване вештине просторне оријентације у реалном или компјутерски симулираном окружењу изведен је општи закључак да се мушкарци боље оријентишу у простору, што се објашњава разликама у когнитивним способностима жена и мушкараца (Moon et al., 2016: 91). Иако се ради о емпиријским, научно утемељеним подацима, њихова генерализација има негативан ефекат јер може да оснажи заблуду о супериорности једног пола у односу на други. Џорџ Боднер (Bodner, цит. у Curry, 2016), аутор једног од типичних тестова за мерење способности просторне когниције, упозорава на опасности генерализације добијених података и скреће пажњу на чињеницу да многе жене поседују снажније способности просторне оријентације него неки мушкарци. Он наглашава да је важно да се не креира мит како се сви мушкарци у простору оријентишу боље од свих жена, јер такви стереотипи могу да имају негативан ефекат. Сасвим је извесно да код жена постоји опасност од интериоризације овог модела, чак и код оних које поседују снажнију просторну когницију од мушкараца. Уколико су научене да су ограничене способности оријентације у простору карактеристика женског пола, жене могу почети да верују да је то и у њиховом случају заиста тако (Bodner, цит. у Curry, 2016). Идеја о жени дезоријентисаној у простору и мушкарцу који је усмерава представља још један стереотип који се на некритички начин прихвата и усваја као природно стање у друштву. Стога, неопходно је да се у уџбеницима модификују устаљени комуникативни обрасци утемељени на једноличним ситуацијама кроз које се испољавају генерализације и стереотипи.

Уједначену расподелу питања везаних за просторне индикације проналазимо у уџбенику Nuovo progetto italiano, код којег су у овом делу представљена два дијалога, један иницира женски лик - студенткиња из иностранства у кругу Кампуса пита непознатог колегу: Scusa, per andare in centro? („Извини, како да дођем до Центра?“) (Marin/Magnelli, 2006: 21); други започиње мушки лик, обраћајући се непознатој женској особи на улици: Scusi, sa dov'è via Alberti? („Извините, знате ли где је улица Алберти?“) (Marin/Magnelli, 2006: 24).

У Chiaro код мини дијалога посвећених тражењу просторних информација у оба идентификована случаја женски лик иницира разговор, а на основу контекста (пре свега формалног обраћања), можемо закључити да се, као што је то обичај код дијалога овог типа, обраћа непознатим пролазницима: Senta, sa dov'è la fermata del tram? („Знате ли где је трамвајска станица?“) (De Savorgnani/ Bergero, 2010: 58); Scusi. Piazza di Porta Maggiore è lontana? („Извините. Трг Porta Maggiore је далеко?“) (De Savorgnani/Bergero, 2010: 58).

у уџбенику Facilissimo такође су доминантни примери у којима женски ликови траже просторне информације. У егземпларном дијалогу женски 
лик се обраћа пролазнику са једним од типичних питања: Scusi, dov'è l'ufficio informazioni? („Извините, где су Информације?“) (Krasa/Riboni, 2014: 26).

У уџбенику Via del Corso нису уочене дијалошке секвенце у којима женски и мушки ликови међусобно размењују просторне информације.

Код питања која се односе на информације о времену нису уочене значајне родне разлике, будући да и женски и мушки ликови подједнако траже временске информације, претежно кроз формално обраћање [нпр. Scusi, signora, sa a che ora parte il treno? („Извините, госпођо, знате ли у колико часова креће воз?“) (Marin/Magnelli, 2006: 79); Mi scusi, che ore sono? („Извињавам се, колико је сати?“) (Krasa/Riboni, 2014: 24).

\subsection{3. Остала питања}

У категорији осталих питања издвојићемоㄹ само она која сматрамо релевантним у контексту анализе родних односа у комуникацији. У Qui Italia једно од таквих је питање: Buonasera, avete un tavolo libero? („Добро вече, имате ли слободан сто?") (Mazzetti et al., 2002: 144) којим Лучио (Lucio) иницира разговор са конобаром у једном ресторану. У разговору учествује и његова партнерка Катерина (Caterina), која се тек накнадно укључује. Премда просто и свакодневно, питање које Лучио упућује конобару открива нам стереотипни образац понашања који је дубоко укорењен у свест о доличном и очекиваном понашању мушкараца и жена у јавној сфери. Мушкарац је тај који већ на почетку говори у име обоје, чиме остварује извесну надмоћ у комуникативном чину. У западној култури идеја о мушкарцу „џентлмену“ који руководи ситуацијом и угађа својој „пратиљи“ начелно има позитивне конотације. Уколико се овај образац интерпретира са становишта феминистичке критике, откривају се његови негативни аспекти, као нпр. чињеница да је у оваквим моделима понашања отеловљена стереотипна идеја о активним, предузимљивим мушкарцима и пасивним женама у чије име они говоре (Haines et al., 2016: 2).

Идентичан разговорни модел проналазимо и у уџбенику Nuovo progetto italiano - троје пријатеља, две жене и један мушкарац, налазе се у ресторану, а мушки лик је тај који комуницира директно са конобарем. Први пут га дозива: Cameriere! („Конобар!“), а приликом другог обраћања тражи мени: Scusi, possiamo avere il listino... il menù? („Извините, можемо ли добити мени?“) (Marin/ Magnelli, 2006: 66).

Сматрамо да уџбеници поред устаљених разговорних модела треба да понуде и алтернативну слику мушко-женских односа, где је жена та која преузима иницијативу и говори у име себе и свог пратиоца. Овакав случај имамо у уџбенику Chiaro, где се женски лик обраћа конобару са питањем: Possiamo ordinare? („Можемо ли наручити?“) (De Sarvognani/Bergero, 2010: 60); такође, женски лик

2 Из анализе ће се искључити питања као што су: hai una penna? („имаш ли оловку?“); hai una sigaretta? („имаш ли цигарету?“); potresti rispondere al telefono? („можеш ли се јавити на телефон?“), јер ни садржај ни контекст разговора нису релевантни из угла родних односа. 
први наручује: Io vorrei un vino rosso. Massimo, cosa dici? („Ја бих желела црвено вино. Масимо, шта кажеш?“)3 (De Sarvognani/Bergero, 2010: 60).

У уџбенику Facilissimo у оквиру лекције Al ristorante („У ресторану“) представљен је још један разговорни модел у којем до изражаја долазе традиционалне родне улоге. Мушки лик по доласку у ресторан пита конобара: Buonasera, c'è un tavolo libero per due? („Добро вече, имате ли слободан сто за двоје?“) (Krasa/ Riboni, 2014: 58). Након што се конобар појављује са менијем, мушки лик опет преузима реч и говори у име себе и женског лика у чијем се друштву налази: Grazie, vorremmo un piatto tipico. Lei, cosa ci consiglia? („Хвала, желели бисмо неко типично јело. Шта нам Ви саветујете?“) (Krasa/Riboni, 2014: 58).

У лекцији Al bar („У кафићу“) у главном дијалогу је опет иста родна расподела: конобар и гости - жена и мушкарац. Мушки лик први наручује за себе, а после њега и женски за себе (Krasa/Riboni, 2014: 50). Судећи по контексту, њих двоје су емотивни партнери и у туристичкој су посети у неименованом италијанском граду. Када конобар донесе њихова пића, по устаљеном принципу мушки лик започиње разговор и тражи информацију која је релевантна за обоје: Scusi, cosa si può fare di interessante qui la sera? („Извините, шта интересантно овде може да се ради навече?“) (Krasa/Riboni, 2014: 50).

У стрип форми карактеристичној за уџбеник Via del Corso представљена је епизода у којој троје протагониста (Ана, Ђани и Бруно) путују за Фиренцу. По доласку у хотел, Ђани се на рецепцији издваја напред, иза њега је Бруно, а на крају стоји Ана. Ђани започиње разговор са рецепционерком и обраћа јој се у трећем лицу множине, чиме се додатно афирмише као представник целе групе: Buongiorno. Abbiamo prenotato tre camere a nome Andreoli („Добар дан. Резервисали смо три собе на име Андреоли.“) (Marin/Diadori, 2018: 56).

У издвојеним комуникативним ситуацијама доминантан интеракцијски модел подразумева да мушки ликови иницирају разговор и говоре у своје и у име женских ликова, чиме се испољава стереотипни приказ личности жена и мушкараца, који почива на дистинкцији између блискости (енг. communion) и предузимљивости (енг. agency) (Haines et al., 2016: 2). Идеја о предузимљивом мушкарцу у овој консталацији подразумева постојање пасивне или мање активне жене у чије име он говори. Сматрамо да су издвојени примери из уџбеника показатељ тога како је и свакодневна интеракција оптерећена родним стереотипима којих често нисмо ни свесни, јер су нам презентовани као бонтон, то јест као општеприхваћене друштвене норме које нису идеолошки условљене.

Као што смо већ антиципирали, у западној култури идеја о мушкарцу џентлмену има позитивне конотације, те се предузмљивост о којој смо говорили

3 У овој реченици имамо једну карактеристику типичну за женски говор - тражење потврде за изречено. Оно што је још упечатљивије јесте даљи ток разговора. На њено питање мушки лик одговара: Mah, io vorrei mangiare il pesce...Prendiamo una bottiglia di vino bianco, va bene? („Ма, ја био желео јести рибу... Хајде да узмемо боцу белог вина, може?“). Након његове реакције, она одмах исказује сагласност и без одупирања пристаје да наручи нешто што је сасвим супротно од њене првобитне намере: Ok, un vino bianco, cosa avete? („Океј, бело вино. Шта имате?“). 
тумачи као одраз бонтона, поштовања и заштитничког става према женама. Из угла теорије амбивалентног сексизма наглашен заштитнички став према женама некада може да долази као резултат тзв. беневолентног сексизма, који се од непријатељског сексизма разликује по томе што подразумева позитивно или пак идеализовано виђење жене (Glick/Fiske, 1997: 121). Како примећују Глик и Фиске (Glick/Fiske, 1997: 121), ова два вида сексизма могу да се разликују по позитивној или негативној вредности која се додељује жени, али оба деле заједничке поставке, нпр. да су жене слабији пол, дакле, оба претпостављају традиционалне родне улоге и имају циљ да оправдају и одрже патријархалне друштвене структуре, те су стога препрека за успостављање родне једнакости.

У корпусу смо пронашли пример када женски лик иницира разговор са мушким ликом, и сматрамо да он на још упечатљивији начин одражава беневолентни сексизам. Реч је о кратком дијалогу из уџбеника Qui Italia осмишљеном према ситуацији у којој женском лику аутомобил стаје на улици услед квара, након чега се она обраћа непознатом мушком лику са речима: E adesso come faccio? („И шта сада да радим?“) (Mazzetti et al., 2002: 141). Непознати пролазник јој без оклевања пружа помоћ. Поред стереотипа да жене нису веште са аутомобилима, кроз ову ситуацију репродукује се идеја о мушкарцу заштитнику и жени која као слабији пол има потребу за његовом помоћи, што се подудара са горепоменутим концептом беневолентног сексизма.

Надаље, када родне стереотипе усађене у поменуту (комуникативну) ситуацију посматрамо кроз културолошки приступ, долазимо до закључка да овај приказ мушко-женских релација заправо представља савремену варијацију добро познатог мотива даме у невољи (енг. damsel in distress), која беспомоћно и пасивно чека спасење од стране мушкарца. Овај мотив вековима се генерацијски преноси кроз народно приповедање и књижевно-уметничко наслеђе, а његова укорењеност у западној култури сведочи о снази когнитивних културних модела који усмеравају наша веровања и очекивања. Са становишта културолошког приступа, стереотипи постоје у индивидуалној свести чланова и чланица једне друштвене заједнице, али су истовремено усађени у културне моделе и представљају један аспекат целокупног друштвеног знања (Stangor/Schaler, 1996: 10). У конструктивистичкој парадигми културно знање није иманентно, већ је продукт оних који га поседују и стварају, те је стога идеолошки условљено (Riley, 2007: 6). Из овог угла, наочиглед бенигна ситуација из уџбеника представља рефлекс когнитивних културних модела прожетих патријархалним родним идеологијама.

У уџбенику Nuovo progetto italiano издваја се дијалог који отац започиње са кћерком, надовезујући се на разговор који је она претходно водила са мајком: Tua madre dice che hai litigato con i tuoi amici. E’vero? („Твоја мајка каже да си се посвађала са пријатељима. Да ли је то тачно?“) (Marin/Magnelli, 2006: 7).

Према подацима из корпуса, у комуникацији са децом највећим делом учествују мајке, што одражава њихову примарну функцију у одгајању. Наведени пример представља изузетак у позитивном смислу зато што презентује про- 
фил оца заинтересованог за емотивне проблеме кћерке. Додуше, премда тиме излазимо из постављеног циља анализе иницијалних исказа, у овом примеру зарад разумевања целовите слике треба навести и исказ којим се разговор завршава, јер се њиме мајка опет враћа у први план и указује се на њену незамењивост. Наиме, након разговора са оцем, кћерка љутито износи закључак: Solo la mia mamma mi capisce! („Само ме моја мама разуме!“) (Marin/Magnelli, 2006: 7).

\subsection{4. Опомене, критике и жалбе}

Опомене које смо уочили у Qui Italia исказују се у јавном простору, формалног су карактера и упућују их особе женског пола. Прва ситуација догађа се у кино сали када непозната особа мушког пола покушава да заузме место поред једног пара, на шта женски лик реагује: Scusi, non vede che questo posto è già occupato? („Извињавам се, зар не видите да је ово место већ заузето?“) (Mazzetti et al., 2002: 192) У другом примеру женски лик се жали продавачу због производа којем је истекао рок: Guardi che questa confezione di latte è scaduta già da due giorni...ecco la data („Видите да је овом млеку истекао рок још пре два дана... ево датума.“) (Mazzetti et al., 2002: 192).

У уџбенику Facilissimo у главном дијалогу мушки лик започиње разговор са рецепционерком хотела жалећи се на собу: Mi scusi tanto, ma la camera non mi piace. E’ piccola e rumorosa per via della strada („Веома ми је жао, али соба ми се не свиђа. Мала је и бучна због близине улице.") (Krasa/Riboni, 2014: 42). У осталим интеракцијама из истог уџбеника женски ликови се на доста изравнији начин жале рецепционеру: La camera non mi piace, ne ha una più grande? („Соба ми се не свиђа, имате ли неку већу?“) (Krasa/Riboni, 2014: 43); La camera non mi piace („Соба ми се не свиђа.“) (Krasa/Riboni, 2014: 43); La doccia non funziona („Туш не ради.“) (Krasa/Riboni, 2014: 43). У дијалогу из лекције Al ristorante („У ресторану“) женски лик исказује жалбу због погрешне наруџбе: Scusi, ma non è quello che ho ordinato. („Извините, али нисам ово наручила.“) (Krasa/Riboni, 2014: 60).

Када посматрамо примере из уџбеника, примећујемо недостатак стратегија учтивости у говору женских ликова, док је насупрот томе исказ мушког лика снажно обележен аполегетским тоном. Изузетак је последњи наведени пример из ресторана где жалби женског лика претходи учтива форма „извините“. Овај маркер учтивости проналазимо и у Qui Italia, код обраћања женског лика у кино сали, али је насупрот њему остатак реченице исказан у изразито критичком тону. У сва три примера обраћања женских ликова користи се форма персирања, што може да се протумачи не само као исказивање поштовања, већ и као дистанцирање од саговорника. Сви искази су изречени на веома директан и бескомпромисан начин, што се не подудара са учтивошћу за коју се сматра да карактерише женски говор. Супротно од очекивања, мушки лик је тај у чијем се говору огледа висок степен учтивости, помоћу које се његова жалба ублажава. Конфронтирајући примере, можемо закључити да су устаљени женско-мушки говорни обрасци овде модификовани, а границе родних улога олабављене. Ови примери доводе у питање парадигму у оквиру теорије доминације према којој 
се кроз женски језик испољавају немоћ и подређеност. Штавише, они више иду у прилог тези коју износе О’Бар и Еткинс (О’Barr and Atkins, 1980: 102), по којој је главни параметар који одређује оно што Робин Лејкоф (Lakoff, 1973) дефинише као женски говор заправо позиција моћи, која није увек условљена родом. Они истичу да „такозвани женски језик није карактеристичан за све жене, нити је ограничен искључиво на жене“. (O’Barr and Atkins, 1980: 102) Слично овоме, Талбот (Talbot, 2003) и Холмс (Holmes, 2006) такође истичу да је комуникације жена и мушкараца знатно комплекснија, те да одлике интеракције не зависе само од рода, већ су условљене контекстом и односима моћи.

У уџбенику Qui Italia уочили смо опомене/критике неформалног карактера, исказане од стране женских ликова у породичном/приватном простору. У првом примеру који издвајамо мајка започиње разговор са сином, постављајући му питање које има илокуциону снагу критике или опомене: Paolo, ma sai che ore sono? Sono le quattro... („Паоло, ма знаш ли колико је сати? Четири је...") (Mazzetti et al., 2002: 83). У другом примеру мајка на индиректан начин опомиње сина због нереда у соби: Che confusione! Che disordine! Di chi è questo maglione? („Каква збрка! Какав неред! Чији је ово џемпер?“) (Mazzetti et al., 2002: 92). На основу комуникативног контекста и конверзацијских стратегија којима женски ликови прибегавају кроз издвојене примере остварује се приказ стереотипне породице у чијем је средишту женска фигура, која брине о деци и домаћинству.

Крос-национално истраживање о подели обавеза везаним за бригу око деце, којим су обухваћене Аустралија, Данска, Италија и Француска, показује да су кућни послови и брига око деце још увек примарно женски послови (Craig/Mullan, 2011: 853), а нешто већа укљученост мушкараца у бригу око деце примећена је у породичним заједницама у којима су жене заспослене (Craig/ Mullan, 2011: 854). Иако је по свему судећи породични модел још увек примарно традиционалан, постоје индикатори да све више очева млађе генерације показује интересовање за активно родитељство, односно за равноправно учешће у одгајању деце (в. Smith Koslowski, 2011).

Иако су брига око кућних послова и одгајања деце још увек превасходно везани за женски домен деловања, сматрамо да увођење ликова очева који преузимају традиционалне женске улоге представља важан допринос процесу натурализације прогресивног егалитарног модела породице у којем сви чланови подједнако доприносе.

У наставку ћемо издвојити примере у којима женски ликови иницирају разговор исказујући опомене партнерима или пријатељима. У уџбенику Nuovo progetto italiano проналазимо пример када женски лик партнеру поставља питање у којем је осетан критички тон: Dove sei stato ieri? Perche' non sei passato a prendermi? („Где си био јуче? Зашто ниси дошао по мене?“) (Marin/Magnelli, 2006: 179).

У уџбенику Via del Corso троје пријатеља путује за Фиренцу, а на почетку вожње женски лик на индиректан начин, у форми питања, опомиње муш- 
ког лика да упали навигатор: Gianni, ma perché non metti il navigatore?4 („Ђани, али зашто не упалиш навигатор?“) (Marin/Diadori, 2018: 56) У повратку за Рим, исти женски лик на индиректан начин исказује жалбу: Gianni! Non mi dire che ste finendo la benzina. („Ђани! Немој ми рећи да је бензин при крају?“) (Marin/ Diadori, 2018: 91).

Индиректност, критике, опомене, жалбе, као и стално понављање захтева генерално су комуникативне стратегије које се вежу за жене. У неформалном регистру овај тип комуникације познат је као „звоцање“ (енг. nagging), а назив се користи и у академској литератури (Soule, 2011). Звоцање можемо дефинисати као упорно убеђивање код којег се уместо укључивања наредби и других агресивнијих или директнијих стратегија ограничава на понављање истог захтева (Soule, 2011: 196). У западној култури доминантна је стереотипна перцепција по којој су у интерперсоналним односима жене те које најчешће комуницирају на овај начин. У истраживању које је спровела Соул (Soule, 2011: 198), а тиче се субјективног мишљења испитаника о томе који пол је више склон звоцању, ова стратегија је одређена као одлика женске комуникације више него мушке. Будући да индиректне критике и опомене иницирају женски ликови, можемо закључити да се кроз уџбенике рефлектује стереотип о женама које “звоцају“.

С друге стране, у издвојеним примерима се на афективном плану у већој или мањој мери јасно очитавају незадовољство и срџба код женских ликова. Ипак, у језику су ове емоције донекле сузбијене и цензурисане, те су уместо директних наредби и критика (нпр. „Спреми собу!“; „Буди се, закаснићеш!“; „Љута сам зато што ниси дошао по мене као што си обећао“; „Укључи навигатор!“5) преточене у индиректне опомене које се граниче са зановетањем. „Зановетање“, као и уопште индиректне критике и опомене које се углавном приписују женама, из угла теорије доминације могу да се тумаче као резултат њихове несигурности у разговору (Lakoff, 1973; Tannen 1991), због које уместо директних захтева и наредби прибегавају ублаженим варијантама, сугестијама, индиректним опоменама и понављањем већ изречених захтева.

\subsection{5. Наредбе}

Родни стереотипи долазе до изражаја пре свега у контекстима у којима се исказују наредбе. У Qui Italia мајка наређује деци: Bambini, smettete di guardare la TV, mettete un po' in ordine la camera e poi fate merenda! („Децо, престаните да

4 Навешћемо и реплику мушког лика, зато што се кроз њу рефлектују родне разлике у говору и до изражаја долази мушка доминација која се испољава кроз језик: Ma quale navigatore! Conosco Firenze come le mie tasche! („Ма који навигатор! Познајем Фиренцу као своје џепове!“) (Marin/Diadori, 2018: 56). Овај пример рефлектује тенденцију мушкараца да се у разговору поставе као стручњаци (Coates, 2013: 133), што можемо интерпретирати као још један вид испољавања ауторитета и доминације.

5 Како бисмо илустровали уочене разлике између говора женских и мушких ликова које иду у прилог теорији доминације, навешћемо и пример када се Бруно обраћа Ђанију у вези са навигатором: Senti, Gianni, ce l'hai il navigatore, no? Che aspetti a metterlo? („Чуј, Ђани, имаш навигатор, је ли тако? Шта чекаш, зашто га не укључиш?“) (Marin/Diadori, 2018: 90). Иако ни Бруно не изриче директну наредбу Ђанију да укључи навигатор, његове вербалне стратегије су свакако много изричитије, директније и бескомпромисније у односу на Анине. 
гледате ТВ, спремите мало собу и после поједите ужину!“) (Mazzetti et al., 2002: 277)

Сличан пример имамо и у Nuovo progetto italiano када се мајка обраћа сину: Dai Lucio, svegliati! Sono già le otto („Дај Лучио пробуди се, већ је осам сати!“) (Marino/Magnelli, 2006: 161).

Женски ликови у наведеним примерима говоре са позиције моћи, али је њихов ауторитет сведен на простор приватне сфере у којем спроводе своју стереотипну функцију мајке и одгајатељице деце. ${ }^{6}$

У другој категорији примера дат је институционални контекст. У уџбенику Qui Italia имамо пример интеракције између директора и секретарице, где директор издаје наредбу: Signorina, per favore, telefoni in banca! („Госпођице, молим Вас, телефонирајте у банку!“) (Mazzetti et al., 2002: 279).

Сличан пример опет проналазимо и у Nuovo progetto italiano, где је у новинској кући мушки лик надређен женском: Pronto, Laura? Sono Parini, dalla redazione. Per favore, girami quell'e-mail con la statistica sulle vendite dei quotidiani. („Хало, да ли је Лаура? Овдје Парини, из редакције. Молим те пошаљи ми онај мејл са статистикама о продаји дневних новина.“) (Marin/Magnelli, 2006: 161).

На формалном плану ове примере класификујемо као директне или учтиве наредбе, али је домен њиховог деловања одређен према стереотипним родним улогама. Поље моћи подељено је на приватну и јавну сферу, а по устаљеном принципу жене су те чији глас остаје у границама кућног простора, док је снага мушке речи призната у друштвеној и професионалној сфери.

\section{7. Комисиви}

Комисиве начелно можемо уврстити у понуде, а у овој категорији мушки ликови се истичу као иницијатори конверзације. Највећи број примера је из уџбеника Qui Italia и већином су смештени у одељак посвећен усвајању израза путем којих се нуди помоћ. У поменутом одељку уочили смо само случајеве мушких ликова који нуде неки вид помоћи женским ликовима. У првом примеру који издвајамо на илустрацији су представљени жена која носи кесе са намирницама и мушкарац који је зауставља да би јој понудио помоћ: Signora, quanta roba ha comprato! Devo aiutarLa? Posso portare io una borsa? („Госпођо, колико сте ствари купили! Треба ли Вам помоћ? Могу ли ја да понесем једну кесу?“) (Mazzetti et al., 2002: 141).

На другој илустрацији приказани су мушкарац и жена у градском превозу, она стоји а он седи и обраћа јој се речима: Signora, vuole sedersi? („Госпођо, да ли бисте желели сести?“) (Mazzetti et al., 2002: 143).

На следећој су приказани жена са кишобраном и мушкарац у ауту који је засуставља да би јој понудио превоз: Teresa, dove vai con questa pioggia? Vuoi un

6 Премда су овде у фокусу искази којима се иницира разговор, треба нагласити да је у целом уџбенику уочен тек један пример оца који делује у породичној сфери. Конкретније, представљен је дијалог у којем отац учи сина како да користи видео рекордер. Очева функција је дакле преношење интелектуалних и практичних вештина, што такође може да се тумачи као стереотип, нарочито ако овај пример конфронтирамо са примером мајке чија је улога сведена на критиковање. 
passaggio? („Тереза, где идеш по овој киши? Желиш ли превоз?“) (Mazzetti et al., 2002: 141).

Наведене ситуације делују посве природно, штавише, чин нуђења помоћи женској особи позитивно се конотира и имплицира да је мушкарац усвојио позитивне обрасце понашања који се цене у западној култури. Овде такође можемо идентификовати даму у невољи као опште место, кроз које нам се предочава и улога мушкарца, коју можемо посматрати као одраз когнитивних културних модела патријархалног друштва у којем мушкарац, као јачи и супериорнији, има усађену дужност да брине о жени. Попут неких претходно издвојених примера, и овај можемо повезати са беневолентним обликом сексизма, будући да заштитничка позиција према женама често корен има у претпоставци да су жене слабији пол (Glick/Fiske, 1997: 121). Стога, упркос начелно позитивном ставу према женама, и овакав вид интеракције где искључиво мушкарци нуде помоћ женама, доприноси преношењу и одржавању родних идеологија утемељеним на патријархалним културним моделима (Glick/Fiske, 1997: 121).

Сматрамо да је поистовећивање сваког вида помоћи коју мушкарац пружа жени са беневолентним сексизмом радикално, неутемељено и контрапродуктивно. С друге стране, сматрамо да је овај теоријски концепт значајан зато што нас усмерава да из критичке перспективе сагледамо наочиглед безопасне примере мушко-женске интеракције, у којој се често под маском општеприхваћених друштвених норми крије заоставштина патријархалних идеологија. У циљу равноправног приказа жена и мушкараца, неопходно је укључити ситуације у којима женски ликови нуде помоћ мушким ликовима, нарочито у ситуацијама које према традиционалним мерилима подразумевају обрнут приступ (нпр. женски лик који нуди превоз мушком, или нуди да заједно са њим понесе кесе из супермаркета). До овог закључка долази и Санчез Бело (Sánchez Bello, 2016: 41), која приказ родних односа у пољу образовања тумачи из угла критичке педагогије, те истиче да да је кроз образовни систем неопходно спроводити све врсте иницијатива кроз које се родне улоге обрћу, јер се на тај начин мушкарци, али и жене, удаљавају од патријархалног модела маскулинитета кроз који се летитимизују ауторитет и доминација мушкараца.

\section{8. Закључак}

Квалитативна анализа омогућила нам је да класификујемо говорне чинове женских и мушких ликова и идентификујемо родне стереотипе и идеолошке поставке које су у њима уткане. Издвојили смо директиве, међу којима су питања у сврху добијања личних информација, питања у сврху добијања просторних и временских информација, остала питања, опомене, критике, жалбе, наредбе; и комисиве, у које смо уврстили понуде. За разлику од неких ранијих истраживања која су показала да жене више употребљавају комисиве, а мушкарци директиве (в. Clyne, 1995: 70-77), установили смо да родне асиметрије најчешће нису у корелацији са самом типологијом говорног чина, већ да произилазе из фактора везаних за одабир конверзацијске теме и контекст у којем се конвер- 
зација одвија. На пример, и женски и мушки ликови користе директиве, или прецизније наредбе, али у различитим контекстима: женски ликови их исказују у простору приватне сфере, где се обраћају деци, док их мушки ликови користе у јавном формалном контексту (нпр. шеф који се обраћа секретарици са надређене позиције, набрајајући обавезе које треба да испуни). На овај начин на основу издвојених примера видимо како се кроз прагматичке разлике рефлектује и различита хијерархијска позиционираност жена и мушкараца у друштву, заснована на неједнаким односима моћи. Надаље, за мушке ликове је типично да инцирају разговор са непознатим особама женског пола, често у циљу исказивања емотивне заинтересованости, као и пракса да се у ресторану конобарима обраћају у своје име и у име партнерке, што тумачимо као показатељ стереотипног схватања о предузмљивом и независном мушкарцу (Haines et al., 2016: 2). ЖКенски ликови интеракцију са непознатим особама мушког пола започињу с циљем тражења помоћи, а мушки с циљем нуђења помоћи, чиме се репродукује мотив даме у невољи (енг. damsel in distress) која зависи од мушкарца заштитника. Овај мотив трансгенерацијски се преноси и чини саставни део когнитивних културних модела западног друштва, а са становишта теорије амбивалентног сексизма он представља рефлекс беневолентног сексизма, према којем наглашен заштитнички однос према женама произилази из веровања да су жене слабији пол. Стога, иако подразумева наочиглед позитивну и идеализовану перцепцију жена, беневолентни сексизам производи исте ефекте као и непријатељски сексизам - оснажује традиционалне родне улоге и има за циљ легитимизацију и одржавање патријархалне матрице, дакле, коси се са принципима родне једнакости (Glick/Fiske, 1997: 121). На основу свих наведених примера можемо закључити да су у комуникативним обрасцима женских и мушких ликова садржане родне идеологије кроз које се родне асиметрије приказују као део природне, свакодневне и идеолошки неутралне комуникације.

Установили смо да женски ликови чешће користе жалбе, као и стратегију која одговара тзв. зановетању, која из угла теорије доминације може да се протумачи као резултат немоћи и несигурности жена (Lakoff, 1973; Tannen, 1991) које уместо директних наредби прибегавају ублаженим варијантама, индиректним опоменама и понављањима претходно изречених примедби. С друге стране, уочили смо примере када се кроз говор женских и мушких ликова стереотипне концепције о мушком и женском говору доводе у питање - нпр. асертиван и директан тон жалбе женског лика, насупрот изражене учтивости која карактерише жалбу мушког лика. Овакви примери представљају одступање од устаљених комуникативних образаца жена и мушкараца и потврђују да тзв. женски говор није карактеристичан за све жене, нити је ограничен искључиво на жене (O’Barr/Atkins, 1980: 102), већ да приликом анализе у обзир треба узети и контекст, односно, позицију и односе моћи међу саговорницима и саговорницама (Talbot, 2003; Holmes, 2006). На ширем плану, мешање разговорних стратегија и превазилажење граница типично женског и типично мушког говора потврђује перформативну природу рода, који се развија и обликује унутар раз- 
личитих друштвених контекста и подразумева сажимање типично женских са типично мушким одликама и њихово интегрисање у један комплексан и флуидан људски идентитет.

\section{Литература}

Грубор, J. (2016). Осврт на испитивање „женског“ говора. Наслеђе, 33, 77-93.

[Grubor, J. (2016). Osvrt na ispitivanje „ženskog“ govora. Nasleđe, 33, 77-93]

Кузмановић Јовановић, А. (2013). Језик и род. Дискурзивна конструкција родне идеологије. Београд: Чигоја штампа

[Kuzmanović-Jovanović, A. (2013). Jezik i rod. Diskurzivna konstrukcija rodne ideologije.

Beograd: Čigoja štampa]

Angelini, E., Tarantola, S. (2020). La rappresentazione dell'immagine di genere (maschile e femminile) nei manuali di italiano L2. Bollettino Itals, 18(85), 1-12.

Ansary, L., Babaii, E. (2003). Subliminal Sexism in Current ESL/EFLTextbooks. Asian EFL Journal, 5(1), 1-15.

Bach, K. (2006). Speech Acts and Pragmatics. In M. Devitt \& R. Hanley (Eds.), Blackwell Guide to the Philosophy of Language (pp. 147-167). Oxford: Blackwell Publishing Ltd. Barton, A., Namatende-Sakwa, L. (2012). The representation of gender in English textbooks in Uganda. Pedagogy Culture and Society, 20(2), 173-190.

Brescoll, V. L., Uhlmann, E. L. (2005). Attitudes Toward Traditional and Nontraditional Parents. Psychology of Women Quarterly, 29(4), 436 - 445.

Brown, P., Levinson, S. (1987). Politeness. Cambridge: Cambridge University Press.

Bucholtz, M. (2014). The Feminist Foundations of Language, Gender, and Sexuality Research. In S. Ehrlich, M. Meyerhoff \& J. Holmes (Eds.), The Handbook of Language, Gender, and Sexuality (pp. 21-47). Hoboken, NJ: Wiley-Blackwell.

Cameron, D. (1995). Verbal hygiene. London: Routledge.

Craig, L., Mullan, K. (2011). How mothers and fathers share childcare: A cross-national time-use comparison. American Sociological Review, 76(6), 834-861.

Clyne, M. (1995). Inter-cultural Communication at Work. Cambridge: Cambridge University Press.

Coates, J. (2013). Women, Men and Language. London: Routledge.

Curry, A. (2016, 18. januar). Men Are Better At Maps Until Women Take This Course. Nautilus. https://nautil.us/issue/32/space/men-are-better-at-maps-until-womentake-this-course

Fairclough, N. (1989). Language and Power. New York: Longman.

Fairclough, N. (1992). Discourse and Social Change. Cambridge: Polity Press.

Filipović, J. (2018). Moć reči: Ogledi iz kritičke sociolingvistike. Beograd: Zadužbina Andrejević.

Glick, P., Fiske, S. T. (1997). Hostile and Benevolent Sexism. Measuring Ambivalent Sexist Attitudes Toward Women. Psychology of Women Quarterly, 21, 119-135.

Glick, P., Rudman, L. A. (2010). Sexism. In J. F. Dovidio, M. Hewstone, P. Glick, V. M. Esses (Eds.), The SAGE Handbook of Prejudice, Stereotyping and Discrimination, (pp. 1-41). Thousand Oaks: SAGE Publications. 
Grazi, J. P. (1989). Are Foreign Language Textbooks Sexist? An Exploration of Modes of Evaluation. Foreign Language Annals, 22(5), 477-486.

Gupta, A., Lee Su Yin, A. (1990). Gender representation in English language textbooks used in the Singapore primary schools. Language and Education, 4(1), 29-50.

Haines, E. L., Deaux K., Lofaro, N. (2016). The Times They Are a-Changing ... or Are They Not? A Comparison of Gender Stereotypes, 1983-2014. Psychology of Women Quarterly, 40(3), 1-11.

Hartman, P. L., Judd, E. L. (1978). TESOL Quarterly, 12(4), 383-393.

Hellinger, M. (1980). "For men must work and women must weep": Sexism in English Language Textbooks used in German Schools. Women's Studies International Quarterly, 3, 267-275.

Holmes, J. (1995). Women, men and politeness. London: Longman.

Holmes, J. (2006). Gendered Talk at Work: Constructing Gender Identity through Workplace Discourse. Malden. MA: Blackwell.

Ivanetić, N. (1995). Govorni činovi. Zagreb: Zavod za lingvistiku Filozofskoga fakulteta Sveučilista u Zagrebu.

Johansson, S., Malmsjö, K. B. (2009). Gender bias in EFL textbook dialogues. Malmö: Malmö högskola/Lärarutbildningen.

Kolarić, A. (2008). Smeh i suze srpskog obrazovanja: rodni i etnički stereotipi u čitankama za srpski jezik i književnost u osnovnoj školi. Reč: časopis za književnost i kulturu, 76(22), 153-192.

Kološ, S. (2018). Gli stereotipi di genere nei manuali d'italiano. Zagreb: Filozofski fakultet Sveučilišta u Zagrebu.

Lakoff, R. (1973). Language and Woman's Place. Language in Society, 2(1), 45-80.

Lee, J., Collins, P. (2010). Construction of gender: a comparison of Australian and Hong Kong English language textbooks. Journal of Gender Studies, 19(2), 121-137.

Mapelli, B. (2008). Progetto Polite: il passato e il futuro. In Atti del convegno Parlante o parlata? La donna fra filosofia, linguaggio e prassi pedagogica (pp. 32-38). Atti del convegno tenutosi il 12 settembre 2007 nella provincia di Lodi.

Mills, S. (2003). Gender and politeness. Cambridge: Cambridge University Press.

Milosavljević, B. (2007). Forme učtivosti u srpskom jeziku. Beograd: Učiteljski fakultet Univerziteta u Beogradu.

Moon, Y., Hwiyeol, J., Jongin, K., Jeong, R. (2016). Exploring Gender Differences in Spatial Orientation Ability on Representing Cognitive Map. International Journal of Psychology and Behavioral Sciences, 6(2), 91-98.

O’Barr, W. M., Atkins, B. K. (1980). “Women's Language” or “Powerless Language”? In S. McConnell-Ginet, N. Borker \& R. Thurman (Eds.), Women and Language in Literature and Society, (pp. 93-110). New York: Praeger.

Pauwels, A. (2003). Linguistic Sexism and Feminist Linguistic Activism. In J. Holmes \& M. Meyerhoff (Eds.), The Handbook of Language and Gender (pp. 550-570). Oxford: Blackwell Publishing

Porreca, K. (1984). Sexism in Current ESL Textbooks. TESOL Quarterly, 18(4), 705-724.

Poulou, S. (1997). Sexism in the discourse roles of textbook dialogues. The Language Learning Journal, 15(1), 68-73. 
Rifkin, B. (1998). Gender Representation in Foreign Language Textbooks: A Case Study of Textbooks of Russian. The Modern Language Journal, 82(2), 217-236.

Riley, P. (2007). Language, Culture and Identity: An Ethnolinguistic Perspective. London: Continuum.

Sánchez Bello, A. (2016). Gender studies in Spain: From theory to educational practice. In P. M. Darder \& J. Paraskeva (Eds), Critical Pedagogy Reader (pp. 39-45). New York: Routledge.

Scott, B. A. (1997). Beauty myth beliefs: Theory, measurement, and the use of a new construct (unpublished doctoral dissertation). University of Minnesota, Minneapolis.

Smith Koslowski, A. (2011). Working fathers in Europe: Earning and caring. European Sociological Review, 27(2), 230-245.

Smith-Lovin, L., Robinson, D. T. (1992). Gender and Conversational Dynamics. In C. L. Ridgeway (Eds.), Gender, Interaction, and Inequality (pp. 122-156). New York: Springer.

Soule, P. K. (2011). The What, When, Who, and Why of Nagging in Interpersonal Relationships. In K. Galvin (Ed.), Making Connections (pp. 193-1999). New York: Oxford University Press.

Stangor, C., Schaller, M. (1996). Stereotypes as individual and collective representations. In C. N. Macrae, C. Stangor \& M. Hewstone (Eds.), Stereotypes and stereotyping (pp. 3-37). New York: Guilford.

Swami, V., Coles, R., Wyrozumska, K., Wilson, E., Salem, N., Furnham, A. (2010). Oppressive Beliefs at Play: Associations among Beauty Ideals and Practices and Individual Differences in Sexism, Objectification of Others, and Media Exposure. Psychology of Women Quarterly, 34(3), 365-379.

Talbot, M. (2003). Gender Stereotypes: Reproduction and Challenge. In J. Holmes \& M. Meyerhoff (Eds.), The Handbook of Language and Gender (pp. 468-486). Oxford: Blackwell.

Tannen, D. (1991). You Just Don't Understand: Women and Men in Conversation. London: Virago.

van Dijk, T. A. (1989). Structures of discourse and structures of power. In J. A. Anderson (Ed.), Communication yearbook, 12 (pp. 18-59). Newbury Park, CA: Sage.

van Dijk, T. A. (2008). Discourse and Context. A sociocognitive approach. Cambridge: Cambridge University Press.

Weary, G., Jacobson, J. A, Edwards, J. A. (2001). Chronic and temporarily activated causal uncertainty beliefs and stereotype usage. Journal of Personality and Social Psychology, 81, 206-219.

\section{Извори}

De Savorgnani, G., Bergero, B. (2010). Chiaro!Corso di italiano. Firenze: Alma Edizioni. Krasa, D., Riboni, A. (2014). Facilissimo. Corso rapido di lingua italiana. Firenze: Alma Edizioni.

Marin, T., Diadori, P. (2018). Via del Corso. Corso di italiano per stranieri. Roma: Edizioni Edilingua. 
Marin, T., Magnelli, S. (2006). Nuovo Progetto Italiano. Corso multimediale di lingua e civiltà italiana. Roma: Edizioni Edilingua.

Mazzetti, A., Falcinelli, M., Servadio, B. (2002). Qui Italia. Corso elementare di lingua italiana per stranieri. Lingua e grammatica. Firenze: Le Monnier.

\section{Nataša D. Vučenović}

\section{Summary}

\section{ANALYSIS OF SPEECH ACTS OF FEMALE AND MALE CHARACTERS IN TEXTBOOKS OF ITALIAN AS A FOREIGN LANGUAGE FROM A GENDER PERSPECTIVE}

In line with the previous body of research about gender stereotypes and sexism in foreign language textbooks, this study addresses the issue of gender in FL textbooks from a pragmalinguistic perspective, which has not been sufficiently explored. The aim of the study is to investigate whether the communication patterns of female and male characters contain stereotypical features typical for two different speech styles defined as women's language and men's language; whether there are differences between the speech acts employed by female and male characters, as suggested in some of the previous research; whether the utterances of female and male characters contain gender stereotypes and sexist connotations that reflect the traditional gender hierarchy. The methodological framework integrates the speech act theory, used as a qualitative research method, and critical discourse analysis, which is crucial for the interpretation of ideologies that shape discourse and social practices. The results indicate that female characters tend to use more complaints; however, their communicative strategies are more direct and assertive, while the complaints of male characters are expressed in an apologetic tone and are characterized by a higher level of politeness. These features challenge the concepts of women's and man's language and align with the theories that explain gender as a performative act. Contrary to this, the results also suggest that dialogical sequences reveal gender stereotypes and sexist connotations that reflect traditional gender hierarchy. However, the main differences do not stem from different speech acts used by male and female characters, but are instead related to context (e.g. both female and male characters use orders; however, those expressed by women are reserved for private sphere, while those of men are expressed in public sphere, which on a larger scale confirms the presence of gender ideologies that support and reproduce unequal power relations).

\section{Key words:}

textbooks, Italian as a foreign language, speech acts, women's language, men's language, sexism, gender ideologies 